\title{
Soil Morphological Properties and Classification of Hebbalagere Micro Watershed in Channagiri Taluk, Davanagere District of Karnataka, India
}

\author{
S. Harshitha ${ }^{1 *}$, Ganapathi ${ }^{1}$, K.T. Gurumurthy ${ }^{1}$, N.S. Mavarkar $^{2}$ and T.M. Soumya ${ }^{2}$ \\ ${ }^{1}$ Department of Soil Science and Agricultural Chemistry, ${ }^{2}$ Department of Agronomy, College \\ of Agriculture, University of Agricultural and Horticultural Sciences, \\ Shivamogga, Karnataka, India \\ *Corresponding author
}

\section{A B S T R A C T}

\begin{tabular}{|c|}
\hline Keywords \\
\hline $\begin{array}{l}\text { Morphology, } \\
\text { Characterization, } \\
\text { Classification, } \\
\text { Taxonomy, Pedons }\end{array}$ \\
\hline Article Info \\
\hline $\begin{array}{l}\text { Accepted: } \\
\text { 06 August } 2018 \\
\text { Available Online: } \\
\text { 10 September } 2018\end{array}$ \\
\hline
\end{tabular}

A study was undertaken to characterize and classify the soils of Hebbalagere micro watershed in Channagiri taluk, Davanagere district of Karnataka. Eleven profiles were studied for the morphological features based on soil heterogeneity. The detailed morphological descriptions of the pedons were done in the field as per the procedure outlined in Soil Survey Manual. The soils were moderately shallow to very deep in depth. The colour of red soil pedons varied from 2.5YR 2.5/3 (dark reddish brown) to 5YR 4/4 (reddish brown), whereas in black soils shown 7.5YR 3/3 (dark brown) to 10YR 4/4 (dark yellowish brown) in colour. Soil texture varied from sandy clay to clay in red soil pedons whereas in case of black soil pedons it was clay. The soil structure was weak fine subangular blocky to moderate medium angular blocky in the pedons under study. The consistency of soil pedons varied from slightly hard to very hard when dry, friable to the firm when moist, slightly sticky to very sticky and slightly plastic to very plastic when wet. Soils studied were classified upto family level. Taxonomically, the soils of the study area were classified under the orders Alfisols, Inceptisols and Vertisols.

\section{Introduction}

Soil morphology is the field observable attributes of the soil within the various soil horizons and the description of the kind and arrangement of the horizons (Buol et al., 2003). A morphological study enables us to detect many essential characters of a soil by mere observation in the field, without analytical investigations, though such observations are of a qualitative nature only. The more common morphological features are colour, structure, texture, consistency, inclusions, water conditions and a few others of lesser significance. Soil characterization provides the information for our understanding of the mineralogical, physical, chemical and microbiological properties of the soils on which we depend on to grow crops, grasslands and sustain forests as well as support homes and social structures. A soil characterization study is a major building block for understanding the soil, classifying it and getting the best understanding of the 
environment. Soil characteristics are affected by a number of natural and human-induced factors. Hence there is a need for systemic study of soil resources characteristics for sustainable land use.

Classification is the grouping of objects in some orderly and logical manner. It is based on the properties of objects for the purpose of their identification and study. The individual soils are grouped into classes of lower category (i.e., soil series), which are further grouped into classes of higher categories (i.e., soil orders). The USDA Soil Taxonomy is property based and concepts are discussed as guidelines, but not as criteria. Properties include horizons and soil morphological properties. The use of definitions for horizons and characteristic diagnostic properties limit descriptions of diagnostic criteria and enhance communication. This supports an accurate natural and concise classification of the pedon. The USDA Soil Taxonomy has six levels, with 12 Orders at the highest level. It defines nine topsoil horizons, 19 subsoil horizons, and 26 and 33 diagnostic properties for organic and inorganic soils, respectively (Soil survey staff, 2003). Therefore, soil classification is helpful in identifying their potential uses, estimating their productivity and transferring agro-technology from research farms to cultivators' fields.

\section{Materials and Methods}

The study area wasa Hebbalagere micro watershed located in Channagiri taluk, Davangere district of Karnataka. The study area lies at latitude 13०59'53.34"N to $14^{\circ} 2^{\prime} 31.20^{\prime \prime} \mathrm{N}$ and longitude $76^{\circ} 0^{\prime} 23.62^{\prime \prime}$ Eto $76^{\circ} 1 ' 26.83$ "E. The micro watershed comes under Southern transition zone (Zone 7) and climate is semi-arid with a mean annual average rainfall of $655 \mathrm{~mm}$. The Hebbalagere micro watershed was surveyed using satellite imagery (IRS P6 LISS-IV and cartostat-1 quick bird imagery), cadastral map and toposheet to collect information on surface features / site characteristics like soil texture, slope, erosion and graveliness. Based on soil heterogeneity, 11 pedons were opened and studied for their morphological features. The detailed morphological descriptions of these pedons were done in the field as per the procedure outlined in Soil Survey Manual.

Soil colour of the pedons was measured both under dry and moist condition using Munsell colour chart. Other morphological characteristics studied were depth of solum, depth of each horizon, texture, structure, consistency at dry, moist and wet conditions, root distribution, coarse fragments, slickenside, quantity of conca and conir, etc. The morphological properties were described as per Soil Survey manual. The horizons were identified and designated according to revisions in Soil Taxonomy.

The pedons under study are classified based on morphological, physical and chemical properties according to Keys to Soil Taxonomy (Soil Survey Staff, 2014). At higher categories (order) the presence or absence of diagnostic horizons which are indications of pedogenic process were considered. At sub-order level, the moisture and temperature regimes were used. At lower categories (great group, sub-group and family), diagnostic subsurface horizons, soil depth, mineralogy, texture, soil chemical properties and drainage are considered. In Hebbalagere micro-watershed, the soils were classified up to family level.

\section{Results and Discussion}

\section{Morphological characteristics of pedons}

Soil morphological characteristics of pedons of Hebbalagere micro watershed is presented in table 1. Soils of the micro-watershed 
derived from peninsular gneissic complex consisting of the granite gneiss parent rock and schist parent rock. Eleven soil pedons were selected based on soil heterogeneity and slope in the micro-watershed. Selected soil pedons fall under nearly level $(0-1 \%$ slope $)$ to very gently sloping ( $1-3 \%$ slope) and exhibited very slight to moderate erosion with moderately well to well drainage condition.

\section{Horizon differentiation}

Horizon differentiation in black soil was relatively weak compared to that of red soils in the study area. In case of black soils, the process of pedoturbation interferes with horizonation. A similar observation was made by Bhattacharjee et al., (1974) in black soils of Deccan plateau. The horizon identification in black soil pedons was made mostly based on intersecting slickensides and horizontal and vertical nature of cracks.

Based on this, three to four horizons could be identified namely; self-mulching surface horizon, horizons with pressure faces and wedge shapes slicken sided sub-soil and horizons with slicken sides and carbonate nodules with varying distribution. Bhattacharyya et al., (2007) studied the morphological properties of red and black soils and observed that black soils, due to their very sticky and very plastic consistency under wet condition, showed well-developed slickensides.

In case of red soil pedons, horizons were identified based on colour, texture, an abundance of coarse fragments. In the red soil, the coarse fragments were high when compared to the black soil. Rudramurthy and Dasog (2001) while studying the associated red and black soils of North Karnataka observed that red soils were characterized by redder hue, high chroma and abundance of coarse fragments in their horizons.

\section{Soil depth}

Soil depth varied from $75 \mathrm{~cm}$ to more than $150 \mathrm{~cm}$ across 11 pedons indicating that they were moderately shallow to very deep. Solum depth reflects the balance between soil formation and soil loss by erosion in any area. The variability in soil depth was due to the variation in topography and slope gradient (Singh and Mishra, 1996). They related to soil depth to physiography; shallow soils on upland pedons due to non-availability of an adequate amount of water for a prolonged period and deeper soils on lower plains due to deposition of finer particles.

\section{Soil colour}

Colour of red soil pedons varied from 2.5YR 2.5/3 (dark reddish brown) to 5YR 4/4 (reddish brown) and 7.5YR 3/3 (dark brown) to $10 \mathrm{YR} 4 / 4$ (dark yellowish brown) in black soil pedons. The soil colour is a function of chemical and mineralogical composition and influenced by topographic position, textural makeup and moisture regimes of the soils. Essentially, the landform position is known to greatly influence the soil colour where intermittent cycles of erosion and runoff intervening not only the matrix colour but also the soil material development. The dark matrix colour of surface horizon was due to presence of high organic matter content (Tripathi et al., 2006). Whereas, the subsurface horizons had comparatively brighter colour throughout the profile, which might be due to low organic matter content and higher iron oxide. In black soils, chroma did not change along depth. This might be due to higher degree of pedoturbation.

\section{Soil texture}

Soil texture, in general, varied from sandy clay to clay. In red soil pedons, soil texture varied from sandy clay to clay whereas in case 
of black soil pedons it was clay. This textural variation was ascribed to differences in composition of parent material, topography, in-situ weathering and translocation of clay by eluviation and age of soils (Prathibha et al., 2018).

\section{Soil structure}

The structure designates the mode of arrangement of the particles and their aggregations, therefore the structural variation in soils were useful to differentiate the horizon (Landey et al., 1982).

In black soil pedons, both surface and subsurface horizons had moderate medium sub-angular blocky structure to moderate medium angular blocky which was due to high clay content in black soils. Sub-angular to angular blocky structure in the sub-soil horizons was due to slicken sides formation in these soils. Dominantly, the soil structure was weak fine sub-angular blocky to moderate medium sub-angular blocky. The weak structural development was ascribed to low clay and low organic carbon content (Sitanggang et al., 2006).

\section{Soil consistency}

The consistency of soil pedons varied from slightly hard to very hard when dry, friable to the firm when moist, slightly sticky to very sticky and slightly plastic to very plastic when wet. The clay content of the soil is known to play a major role in the expression of consistency.

The soils of eroded land were low in clay content due to dispersion and removal and consequently the consistency status was lower than that of the soil unaffected by the erosion. The attribute and relief were considered to have a significant bearing on soil consistency (Anjali and Hebbara, 2017).

\section{Soil classification}

The soils of the study area were classified up to family level as per Keys to Soil Taxonomy (Soil survey staff, 2014) based on the morphological, physical and chemical properties of soils. These soils were grouped into three orders viz., Alfisols, Inceptisols and Vertisols. The soils classified upto family level is presented in table 2 .

The pedons morphology exhibited argillic subsurface diagnostic horizon in pedons 1,2 , $3,4,5,6,8$ and 11 whereas, pedons 7,9 and 10 evidenced the presence of cambic horizon. The significant translocation of illuvial clay from the surface horizon to the subsurface horizon qualified the subsurface horizon to be designated as an argillic horizon (Chari, 2015)

The pedons 1, 2, 3, 4, 5, 6, 8 and 11 were classified under order Alfisols as they possessed argillic horizon and base saturation more than 35 per cent. Since moisture regime was ustic, it was classified under suborder ustalfs.

The pedon 5 was classified as rhodustalfs due to occurrence of sub-horizons in the upper 100 $\mathrm{cm}$ of the argillic horizon or throughout the entire argillic horizon if less than $100 \mathrm{~cm}$ thick, more than 50 per cent colors that have hue of 2.5YR or redder and value, moist, of 3 or less. Pedons 1, 2, 3, 4, 6, 8 and 11 were classified as haplustalfs since they do qualify under other ustalfs but does not have characteristics of any other great groups.

At the sub-group level, because of absence of inter-gradation with other taxa or an extragradation from the central concept, the pedons 2, 3, 5 and 11 were keyed out as Typic haplustalfs and Typic rhodustalfs. Pedons 1, 4, 6 and 8 were grouped under Ultic Haplustalfs as they have argillic horizon with a base saturation of less than 75 per cent throughout. 
Table.1 Morphological characteristics of pedons of Hebbalagere micro watershed

\begin{tabular}{|c|c|c|c|c|c|c|c|c|c|c|}
\hline \multirow[t]{2}{*}{ Horizon } & \multirow{2}{*}{$\begin{array}{l}\text { Depth } \\
\text { (cm) }\end{array}$} & \multicolumn{2}{|c|}{ Colour } & \multirow[t]{2}{*}{ Texture } & \multirow[t]{2}{*}{ Structure } & \multicolumn{2}{|c|}{ Consistency } & \multirow[t]{2}{*}{ Stickiness } & \multirow[t]{2}{*}{ Root } & \multirow[t]{2}{*}{ Special features } \\
\hline & & Dry & Moist & & & Dry & Moist & & & \\
\hline & & & & & \multicolumn{4}{|l|}{ Pedon 1} & & \\
\hline $\mathbf{A p}$ & $0-20$ & $7.5 \mathrm{YR} 4 / 3$ & 7.5YR $3 / 3$ & $\mathrm{sc}$ & $2 \mathrm{msbk}$ & $\mathrm{h}$ & $\mathrm{fr}$ & $\mathrm{ms}$ & vf-c & \multirow{5}{*}{$\begin{array}{l}\text { Micro features like cracks and } \\
\text { clay cutons was observed }\end{array}$} \\
\hline$\overline{\mathbf{B t}_{1}}$ & $20-45$ & $7.5 \mathrm{YR} 4 / 3$ & 7.5YR 3/3 & $\mathrm{sc}$ & $2 \mathrm{msbk}$ & $\mathrm{h}$ & fr & $\mathrm{ms}$ & vf-m & \\
\hline $\mathbf{B t}_{2}$ & $45-78$ & $7.5 \mathrm{YR} 4 / 3$ & 7.5YR 3/3 & $\mathrm{sc}$ & $2 \mathrm{msbk}$ & $\mathrm{h}$ & fr & $\mathrm{ms}$ & $v f-c$ & \\
\hline$\overline{\mathbf{B t}_{3}}$ & $78-110$ & $7.5 \mathrm{YR} 4 / 3$ & $7.5 Y R 3 / 3$ & $\mathrm{sc}$ & $2 \mathrm{msbk}$ & $\mathrm{h}$ & fr & $\mathrm{ms}$ & - & \\
\hline \multirow[t]{2}{*}{$\overline{\mathbf{B t}_{4}}$} & $110-152$ & 7.5YR 4/3 & 7.5YR 3/4 & $\mathrm{sc}$ & $2 \mathrm{msbk}$ & $\mathrm{h}$ & $\mathrm{fr}$ & $\mathrm{ms}$ & - & \\
\hline & & & & & \multicolumn{4}{|l|}{ Pedon 2} & & \\
\hline Ap & $0-16$ & 5YR $2.5 / 2$ & $5 \mathrm{YR} 3 / 2$ & $\mathrm{c}$ & $2 \mathrm{msbk}$ & $\mathrm{mh}$ & fr & $\mathrm{ms}$ & vf-m & \multirow[t]{6}{*}{ Clay cutons were observed } \\
\hline $\mathbf{B t}_{1}$ & $16-36$ & 5YR $2.5 / 2$ & $5 Y R 3 / 2$ & $\mathrm{c}$ & $2 \mathrm{msbk}$ & $\mathrm{mh}$ & fr & $\mathrm{ms}$ & vf-m & \\
\hline $\mathbf{B t}_{2}$ & $36-61$ & $5 \mathrm{YR} 2.5 / 2$ & $5 Y R 3 / 3$ & $\mathrm{c}$ & $2 \mathrm{msbk}$ & $\mathrm{mh}$ & fr & $\mathrm{ms}$ & vf-m & \\
\hline $\mathrm{Bw}_{1}$ & $61-87$ & $5 Y R 2.5 / 2$ & $10 Y R 3 / 2$ & $\mathrm{c}$ & $2 \mathrm{msbk}$ & $\mathrm{mh}$ & fr & $\mathrm{ms}$ & vf-m & \\
\hline $\mathrm{Bw}_{2}$ & $87-99$ & $5 \mathrm{YR} 2.5 / 2$ & $10 Y R 3 / 2$ & $\mathrm{c}$ & $2 \mathrm{msbk}$ & $\mathrm{mh}$ & fr & $\mathrm{ms}$ & - & \\
\hline \multirow[t]{2}{*}{$\mathrm{Bw}_{\mathbf{3}}$} & $99-130+$ & 5YR $2.5 / 2$ & $10 Y R 3 / 2$ & $\mathrm{c}$ & $2 \mathrm{msbk}$ & $\mathrm{mh}$ & fr & $\mathrm{ms}$ & - & \\
\hline & & & & & \multicolumn{4}{|l|}{ Pedon 3} & & \multirow{5}{*}{ Clay cutons were observed } \\
\hline Ap & $0-17$ & $5 Y R 3 / 3$ & 5YR $2.5 / 2$ & $\mathrm{c}$ & $2 \mathrm{msbk}$ & $\mathrm{sh}$ & fr & $\mathrm{ms}$ & vf-m & \\
\hline$\overline{\mathbf{B t}_{1}}$ & $17-40$ & $5 Y R 3 / 3$ & 5YR $2.5 / 2$ & $\mathrm{c}$ & $2 \mathrm{msbk}$ & sh & fr & $\mathrm{ms}$ & vf-m & \\
\hline $\mathbf{B t}_{2}$ & $40-65$ & $5 Y R 3 / 3$ & 5YR $2.5 / 2$ & $\mathrm{c}$ & $2 \mathrm{msbk}$ & sh & fr & $\mathrm{ms}$ & vf-m & \\
\hline $\mathrm{Bt}_{\mathbf{3}}$ & $65-90$ & $5 Y R$ 4/3 & 5YR $2.5 / 2$ & $\mathrm{c}$ & $2 \mathrm{msbk}$ & sh & $\mathrm{fr}$ & $\mathrm{ms}$ & vf-m & \\
\hline
\end{tabular}


Int.J.Curr.Microbiol.App.Sci (2018) 7(9): 444-454

\begin{tabular}{|c|c|c|c|c|c|c|c|c|c|c|}
\hline \multirow[t]{2}{*}{ Horizon } & \multirow{2}{*}{$\begin{array}{c}\text { Depth } \\
(\mathbf{c m})\end{array}$} & \multicolumn{2}{|c|}{ Colour } & \multirow[t]{2}{*}{ Texture } & \multirow[t]{2}{*}{ Structure } & \multicolumn{2}{|c|}{ Consistency } & \multirow[t]{2}{*}{ Stickiness } & \multirow[t]{2}{*}{ Root } & \multirow[t]{2}{*}{ Special features } \\
\hline & & Dry & Moist & & & Dry & Moist & & & \\
\hline & & & & & \multicolumn{4}{|l|}{ Pedon 4} & & \multirow{4}{*}{$\begin{array}{c}\text { Micro features like clay cutons were } \\
\text { observed }\end{array}$} \\
\hline$\overline{A p}$ & $0-15$ & 10YR $3 / 2$ & 10YR 2/2 & sc & $2 \mathrm{msbk}$ & $\mathrm{h}$ & fi & $\mathrm{ms}$ & $v f-c$ & \\
\hline $\mathbf{B t}_{1}$ & $15-28$ & $10 Y R 3 / 2$ & 10YR 2/2 & $\mathrm{c}$ & $2 \mathrm{msbk}$ & $\mathrm{h}$ & fi & vs & $\mathrm{f}-\mathrm{c}$ & \\
\hline \multirow[t]{2}{*}{$\mathbf{B t}_{2}$} & $28-75$ & $10 Y R 3 / 2$ & 10YR 7/1 & sc & $2 \mathrm{msbk}$ & $\mathrm{h}$ & fi & $\mathrm{ms}$ & - & \\
\hline & & & & & \multicolumn{4}{|l|}{ Pedon 5} & & \multirow{5}{*}{$\begin{array}{c}\text { Stoniness and clay cutons were } \\
\text { observed }\end{array}$} \\
\hline $\mathbf{A p}$ & $0-15$ & $\begin{array}{l}2.5 \mathrm{YR} \\
3 / 4\end{array}$ & $\begin{array}{l}2.5 \mathrm{YR} \\
2.5 / 3\end{array}$ & $\mathrm{c}$ & $2 \mathrm{msbk}$ & $\mathrm{h}$ & fi & $\mathrm{ms}$ & vf-m & \\
\hline $\mathbf{B t}_{1}$ & $15-30$ & $\begin{array}{l}2.5 \mathrm{YR} \\
3 / 4\end{array}$ & $2.5 Y R 3 / 4$ & $\mathrm{c}$ & $2 \mathrm{msbk}$ & $\mathrm{h}$ & fi & $\mathrm{ms}$ & vf-m & \\
\hline $\mathbf{B t}_{2}$ & $30-50$ & $\begin{array}{l}2.5 \mathrm{YR} \\
3 / 4\end{array}$ & $2.5 \mathrm{YR} 3 / 3$ & sc & $2 \mathrm{msbk}$ & $\mathrm{h}$ & fr & $\mathrm{ms}$ & vf-m & \\
\hline $\mathrm{Bt}_{3}$ & $50-65$ & $\begin{array}{l}2.5 \mathrm{YR} \\
3 / 4\end{array}$ & $2.5 Y R 3 / 4$ & sc & $1 \mathrm{fsbk}$ & $\mathrm{h}$ & fr & $\mathrm{ms}$ & vf-m & \\
\hline $\mathbf{B t}_{4}$ & $65-83$ & $\begin{array}{l}2.5 \mathrm{YR} \\
3 / 4\end{array}$ & $2.5 Y R 3 / 4$ & sc & $1 \mathrm{fsbk}$ & $\mathrm{h}$ & fr & $\mathrm{ms}$ & vf-m & \\
\hline \multirow[t]{2}{*}{$\mathbf{B C}$} & $83-93$ & $\begin{array}{l}2.5 Y R \\
3 / 4\end{array}$ & $2.5 \mathrm{YR} 4 / 6$ & $\mathrm{scl}$ & $2 \mathrm{msbk}$ & $\mathrm{h}$ & fr & $\mathrm{ms}$ & vf-m & \\
\hline & & & & & Pedon 6 & & & & & \\
\hline $\mathbf{A p}$ & $0-20$ & $5 Y R 4 / 4$ & $5 Y R 3 / 3$ & sc & $2 \mathrm{msbk}$ & $\mathrm{mh}$ & $\mathrm{fr}$ & $\mathrm{ms}$ & vf-m & \multirow{4}{*}{ Clay cutons were observed } \\
\hline $\mathbf{B t}_{1}$ & $20-50$ & $5 Y R 4 / 4$ & 5YR $2.5 / 2$ & sc & $2 \mathrm{msbk}$ & $\mathrm{mh}$ & fr & $\mathrm{ms}$ & vf-m & \\
\hline $\mathbf{B t}_{2}$ & $50-75$ & $5 Y R 4 / 4$ & $5 Y R 3 / 3$ & sc & $2 \mathrm{msbk}$ & $\mathrm{mh}$ & fr & $\mathrm{ms}$ & vf-m & \\
\hline $\mathrm{Bt}_{\mathbf{3}}$ & $75-110$ & $5 Y R 4 / 4$ & $5 Y R 3 / 3$ & sc & $2 \mathrm{msbk}$ & $\mathrm{mh}$ & $\mathrm{fr}$ & $\mathrm{ms}$ & - & \\
\hline $\mathbf{B t}_{4}$ & $\begin{array}{l}110- \\
160+\end{array}$ & $5 Y R 4 / 4$ & $5 Y R 3 / 3$ & sc & $2 \mathrm{msbk}$ & $\mathrm{mh}$ & fr & $\mathrm{ms}$ & - & \\
\hline
\end{tabular}


Int.J.Curr.Microbiol.App.Sci (2018) 7(9): 444-454

\begin{tabular}{|c|c|c|c|c|c|c|c|c|c|c|}
\hline \multirow[t]{2}{*}{ Horizon } & \multirow{2}{*}{$\begin{array}{l}\text { Depth } \\
(\mathrm{cm})\end{array}$} & \multicolumn{2}{|c|}{ Colour } & \multirow[t]{2}{*}{ Texture } & \multirow{2}{*}{ Structure } & \multicolumn{2}{|c|}{ Consistency } & \multirow[t]{2}{*}{ Stickiness } & \multirow[t]{2}{*}{ Root } & \multirow[t]{2}{*}{ Special features } \\
\hline & & Dry & Moist & & & Dry & Moist & & & \\
\hline & & & & & Pedon 7 & & & & & \\
\hline $\mathbf{A p}$ & $0-20$ & $10 Y R 3 / 2$ & $10 \mathrm{YR} 2 / 2$ & $\mathrm{c}$ & $2 \mathrm{mabk}$ & $\mathrm{h}$ & fi & vs & $v f-m$ & \multirow[t]{3}{*}{$\begin{array}{c}\text { Micro features like cracking was } \\
\text { observed }\end{array}$} \\
\hline $\mathrm{Bw}_{1}$ & $20-38$ & 10YR $3 / 2$ & $10 \mathrm{YR} 2 / 2$ & $\mathrm{c}$ & $2 \mathrm{mabk}$ & $\mathrm{h}$ & fi & vs & vf-m & \\
\hline$\overline{\mathrm{Bw}_{2}}$ & $38-60$ & 10YR 3/2 & 10YR 2/1 & $\mathrm{c}$ & $2 \mathrm{mabk}$ & $\mathrm{h}$ & fi & vs & $\mathrm{vf}-\mathrm{c}$ & \\
\hline $\mathrm{Bw}_{3}$ & $60-80$ & 10YR $3 / 2$ & 10YR 2/1 & $\mathrm{c}$ & $2 \mathrm{mabk}$ & $\mathrm{h}$ & fi & vs & & \\
\hline $\mathrm{Bw}_{4}$ & $80-95$ & 10YR $3 / 2$ & 10YR 2/1 & $\mathrm{c}$ & $2 \mathrm{mabk}$ & $\mathrm{h}$ & fi & vs & & \\
\hline \multirow[t]{2}{*}{$\overline{\mathrm{Bw}_{5}}$} & $\begin{array}{c}95- \\
114+\end{array}$ & $10 \mathrm{YR} 3 / 2$ & 10YR 2/1 & $\mathrm{c}$ & $2 \mathrm{mabk}$ & $\mathrm{h}$ & fi & vs & & \\
\hline & & & & & Pedon 8 & & & & & \\
\hline $\mathbf{A p}$ & $0-14$ & $\begin{array}{l}7.5 \mathrm{YR} \\
3 / 2\end{array}$ & $\begin{array}{l}7.5 \mathrm{YR} \\
2.5 / 3\end{array}$ & $\mathrm{c}$ & $2 \mathrm{mabk}$ & $\mathrm{mh}$ & $\mathrm{fr}$ & $\mathrm{ms}$ & vf-m & \multirow[t]{6}{*}{ Stoniness and clay cutons were observed } \\
\hline$\overline{\mathbf{B t}_{1}}$ & $14-29$ & $\begin{array}{l}7.5 \mathrm{YR} \\
3 / 2\end{array}$ & $5 Y R 3 / 3$ & $\mathrm{sc}$ & $2 \mathrm{mabk}$ & $\mathrm{mh}$ & $\mathrm{fr}$ & $\mathrm{ms}$ & vf-m & \\
\hline $\mathbf{B t}_{2}$ & $29-49$ & $\begin{array}{l}7.5 \mathrm{YR} \\
3 / 2\end{array}$ & 5YR 3/4 & $\mathrm{sc}$ & $2 \mathrm{mabk}$ & $\mathrm{mh}$ & $\mathrm{fr}$ & $\mathrm{ms}$ & vf-m & \\
\hline $\mathbf{B t}_{3}$ & $49-71$ & $\begin{array}{l}7.5 \mathrm{YR} \\
3 / 2\end{array}$ & $2.5 \mathrm{YR} 3 / 4$ & $\mathrm{sc}$ & $2 \mathrm{mabk}$ & $\mathrm{mh}$ & $\mathrm{fr}$ & $\mathrm{ms}$ & - & \\
\hline $\mathrm{Bt}_{4}$ & $71-98$ & $\begin{array}{l}7.5 \mathrm{YR} \\
3 / 2\end{array}$ & 7.5YR 3/4 & sc & $2 \mathrm{mabk}$ & $\mathrm{mh}$ & $\mathrm{fr}$ & $\mathrm{ms}$ & - & \\
\hline $\mathrm{Bt}_{5}$ & $\begin{array}{c}98- \\
129+\end{array}$ & $\begin{array}{l}7.5 \mathrm{YR} \\
3 / 2\end{array}$ & 7.5YR 3/4 & $\mathrm{sc}$ & $2 \mathrm{mabk}$ & $\mathrm{mh}$ & $\mathrm{fr}$ & $\mathrm{ms}$ & - & \\
\hline
\end{tabular}




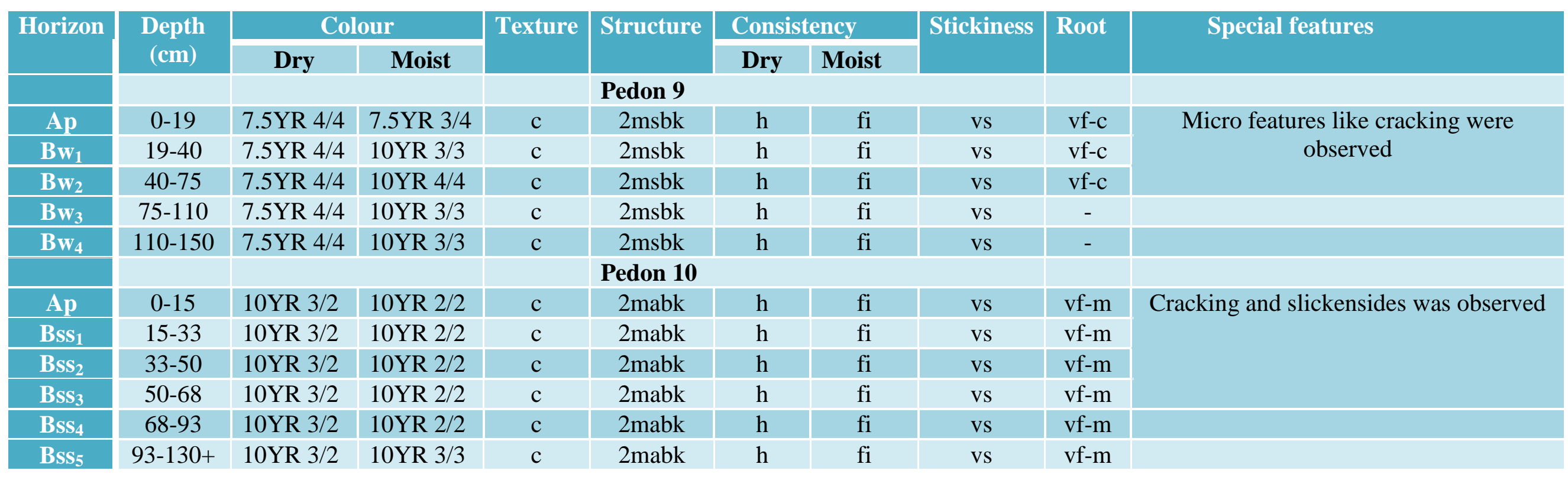

\begin{tabular}{|c|c|c|c|c|c|c|c|c|c|c|}
\hline \multirow[t]{2}{*}{ Horizon } & \multirow{2}{*}{$\begin{array}{l}\text { Depth } \\
(\mathrm{cm})\end{array}$} & \multicolumn{2}{|c|}{ Colour } & \multirow[t]{2}{*}{ Texture } & \multirow[t]{2}{*}{ Structure } & \multicolumn{2}{|c|}{ Consistency } & \multirow[t]{2}{*}{ Stickiness } & \multirow[t]{2}{*}{ Root } & \multirow[t]{2}{*}{ Special features } \\
\hline & & Dry & Moist & & & Dry & Moist & & & \\
\hline & & & & & Pedon 11 & & & & & \multirow{4}{*}{$\begin{array}{c}\text { Micro features like clay cutons were } \\
\text { observed }\end{array}$} \\
\hline $\mathbf{A p}$ & 0-19 & 7.5YR 4/4 & 7.5YR $3 / 3$ & sc & 1msbk & $\mathrm{mh}$ & $\mathrm{fr}$ & $\mathrm{ms}$ & vf-m & \\
\hline $\mathbf{B t}_{1}$ & $19-49$ & 7.5YR 4/4 & $5 Y R 3 / 3$ & sc & $2 \mathrm{msbk}$ & $\mathrm{mh}$ & $\mathrm{fr}$ & $\mathrm{ms}$ & vf-m & \\
\hline$\overline{\mathrm{Bt}_{2}}$ & $49-75$ & 7.5YR 4/4 & 5YR 3/4 & $\mathrm{sc}$ & $2 \mathrm{msbk}$ & $\mathrm{mh}$ & fr & $\mathrm{ms}$ & vf-m & \\
\hline$\overline{\mathbf{B t}_{3}}$ & 75-106 & 7.5YR 4/4 & $2.5 \mathrm{YR} 4 / 4$ & sc & $2 \mathrm{msbk}$ & $\mathrm{mh}$ & fr & $\mathrm{ms}$ & - & \\
\hline$\overline{\mathbf{B t}_{4}}$ & $106-128$ & 7.5YR 4/4 & $2.5 \mathrm{YR} 3 / 3$ & sc & $2 \mathrm{msbk}$ & $\mathrm{mh}$ & fr & $\mathrm{ms}$ & - & \\
\hline $\mathrm{Bt}_{5}$ & $\begin{array}{l}128- \\
140+\end{array}$ & 7.5YR 4/4 & $2.5 \mathrm{YR} 3 / 4$ & sc & $1 \mathrm{msbk}$ & $\mathrm{mh}$ & fr & $\mathrm{ms}$ & - & \\
\hline
\end{tabular}

c-clay; sc-sandy clay; scl-sandy clay loam; h-hard; mh-moderately hard; sh-slightly hard; fr-friable; fi-firm; m-moderate; sbk-sub angular blocky; abk-angular blocky; ms-moderately sticky; vs-very sticky; vf-very fine; c-coarse, m-medium. 
Table.2 Taxonomical classification of soil pedons of Hebbalagere micro watershed

\begin{tabular}{|c|l|}
\hline Pedon No. & Soil classification \\
\hline 1 & Fine, mixed, active, Isohyperthermic, Ultic Haplustalfs \\
\hline 2 & Fine, mixed, superactive, Isohyperthermic, Typic Haplustalfs \\
\hline 3 & Fine, mixed, superactive, Isohyperthermic, Typic Haplustalfs \\
\hline 4 & Fine, mixed, active, Isohyperthermic, Ultic Haplustalfs \\
\hline 5 & Fine, mixed, active, Isohyperthermic, Typic Rhodustalfs \\
\hline 6 & Fine, mixed, superactive, Isohyperthermic, Ultic Haplustalfs \\
\hline 7 & Very fine, mixed, superactive, Isohyperthermic, Typic Haplustepts \\
\hline 8 & Fine, mixed, superactive, Isohyperthermic, Ultic Haplustalf \\
\hline 9 & Fine, mixed, superactive, Isohyperthermic, Typic Haplustepts \\
\hline 10 & Fine, mixed, superactive, Isohyperthermic, Typic Hapluserts \\
\hline 11 & Fine, mixed, superactive, Isohyperthermic, Typic Haplustalfs \\
\hline
\end{tabular}

The soils of pedon 7 and 9 were grouped under order Inceptisols, because of the presence of cambic horizon. Because of the prevailing ustic moisture regime, they were identified as ustepts under suborder. At the great group level, pedons 7 and 9 were classified as haplustepts. These pedons which exhibited no inter-gradation with other taxa or an extra-gradation from the central concept were keyed out as Typic haplustepts.

Pedon 10 was classified as Vertisols at the order level and had a weighted average of > 30 per cent clay in all the horizons down to a depth of $100 \mathrm{~cm}$ and possessed cracks that open and close periodically. This pedon had a layer (> $25 \mathrm{~cm}$ thickness) of slickensides and wedge shaped peds within $100 \mathrm{~cm}$ from the soil surface. At sub order level, pedon 10 was classified as ustert because of ustic moisture regime. At the great group level, keyed out as haplusterts. Because of absence of intergradation with other taxa or an extragradation from the central concept, the pedon was keyed out as Typic haplusterts.

Classification of pedons at family level was done based on particle size, mineralogical class, CEC and temperature. Pedons 1, 2, 3, 4, $5,6,8,9,10$ and 11 contained more than 35 but less than 60 per cent clay (weighted average) in the control section, which led to the grouping of these pedons under fine particle size class. Pedon 7 contained more than 60 per cent clay (weighted average) in the control section and was classified as very fine particle size class.

MAST (Mean annual soil temperature) was computed by adding $3.5^{\circ} \mathrm{C}$ to the MAAT (Mean annual air temperature) which was 26 ${ }^{0} \mathrm{C}$ in the micro-watershed. Based on this, the study area was classified under hyperthermic (MAST $>22{ }^{0} \mathrm{C}$ ). The difference between mean summer and winter temperatures was less than $6{ }^{0} \mathrm{C}$ making it isohyperthermic.

Pedons 2, 3, 5, 6, 7, 8, 9, 10 and 11 were classified as superactive active while pedons 1 and 4 were classified as active. The cation exchange activity class of above pedons was rated as superactive as the ratio of CEC to clay exceeded 0.60 while in remaining pedons it was active as the CEC to clay content ratio was between 0.4 to 0.6 .

Soils of Hebbalagere micro watershed were grouped into 11 soil series like Billahalli (BLH), Chennagiri (CNG), Ganduganahankalu (GDG), Hireganguru 
(HRG), Jammapura (JMP), Lakshmisagar (LKS), Mangenahalli (MGN), Pandavamatte (PDM), Rangapura Thanda (RGT), Rangapura (RGP) and Vaddanala (VDN) by considering soil depth, amount and nature of gravel, depth of occurrence of gravel layer and nature of substratum present below soil and horizon sequence.

Soils of Hebbalagere micro-watershed varied with respect to morphological, physical and chemical properties and were classified based on these at the order level as Alfisols, Inceptisols and Vertisols. Similar approach was followed by Prathibha et al., (2018) in classifying the soil resources of Kavalur-1 micro-watershed in Koppal district of Karnataka.

Eleven representative soil pedons were identified in Hebbalagere micro-watershed which were characterized and classified. The soils were moderately shallow to very deep in depth. The soil texture varied from sandy clay to clay in red soils and largely clay in black soils. Irrespective of soil type, the soil structure remained largely sub angular blocky. Slickensides were observed in pedon 10. The consistency of soil pedons varied from slightly sticky to very sticky and slightly plastic to very plastic when wet. Taxonomically, the soils of the Hebbalagere micro-watershed were classified under the orders Alfisols (pedons 1, 2, 3, 4, 5, 6, 8 and 11), Inceptisols (pedons 7 and 9) and Vertisols (pedon 10).

\section{References}

Anjali, M. C. and Hebbara, M., 2017, Soil morphological properties and classification of Kavalur subwatershed of Koppal district, Karnataka. Int. J. Pure App. Biosci., 5(4):180-190.

Bhattacharjee, J. C., Landey, R. J. and Kaloande, A. R., 1974, A new approach to studying the Vertisol morphology. Symp. Soil Genesis, Soil classification and land management.

Bhattacharyya, T., Chandran, P., Ray, S. K., Mandal, C., Pal, D. K., Venugopalan, M. V., Durge, S. L., Srivastava, P., Dubey, P. N., Kamble, G. K., Sharma, R. P., Wani, S. P. Rego, T. J., Ramesh, V. and Manna, M. C., 2007, Morphological properties of red and black soils of selected bench mark spots in semi-arid tropics of India. J. SAT Agric. Res., 3(1): 104-129.

Buol, Stanley, W., Southard, Randal, J., Graham, Robert, C., Mcdaniel and Paul, A., 2003, Soil Genesis and Classification, $5^{\text {th }}$ Edition. Ames, Lowa: Lowa State Press, A Blackwell Pub. Co. p. 494.

Chari, M. K., 2015, Soil resource inventory of Chikmegeri-3 micro-watershed in Koppal district using remote sensing and GIS techniques. Ph.D., Thesis, Univ. Agric. Sci., Dharwad, Karnataka, India.

Landey, R. I., Hirekerur, L. R. and Krishnamurthy, P., 1982, Morphology, genesis and classification of black soils. In: Review of Soil Research in India Part- II. $12^{\text {th }}$ International Congress of Soil Science, New Delhi, pp. 484-498.

Prathibha, K. S., Hebbara, M., Patil, P. L. and Anjali, M. C., 2018, Soil morphological properties and classification of kavalur1 micro-watershed of Koppal district, Karnataka. J. Pharmacognosy Phytochem., 7(4): 167-173.

Rudramurthy, H. V. AND Dasog, G. S., 2001, Properties and genesis of associated red and black soils in north Karnataka. J. Indian Soc. Soil Sci., 49(2): 301-309.

Singh, V. N. AND Mishra, B. B., 1996, Pedogenic characterization of some typic soils of Gandak command area of Bihar for evaluation of land suitability. J. Indian Soc. Soil Sci., 44: 136-142. 
Sitanggang, M., Rao, Y. S., Ahmed, N. AND Mahapatra, S. K., 2006, Characterization and classification of soils in watershed area of Shikohpur, Gurgaon district, Haryana. J. Indian Soc. Soil Sci., 54: 106-110.

Soil Survey Staff, 2003, Keys to Soil Taxonomy (9th edn). United States, Department of Agriculture, Washington, D. C., USA.
Soil Survey Staff, 2014, Keys to Soil Taxonomy (Twelth edition). United States, Department of Agriculture, Washington, D. C., USA.

Tripathi, L. R., Verma, K. S., Patial AND Singh, 2006, Characteristics, classification and suitability of soils for major crops of Kiar-Nagali microwatershed in north-west Himalayas. J. Indian Soc. Soil Sci., 54(2): 131-136.

\section{How to cite this article:}

Harshitha, S., Ganapathi, K.T. Gurumurthy, N.S. Mavarkar and Soumya, T.M. 2018. Soil Morphological Properties and Classification of Hebbalagere Micro Watershed in Channagiri Taluk, Davanagere District of Karnataka, India. Int.J.Curr.Microbiol.App.Sci. 7(09): 444-454. doi: https://doi.org/10.20546/ijcmas.2018.709.054 